- ORIGINAL ARTICLE

Volume 10 Issue 12018

DOI: 10.21315/eimj2018.10.1.7

ARTICLE INFO

Submitted: $12-02-2018$

Accepted: 03-03-2018

Online: 30-03-2018

\section{The Structural Framework, Implementation Strategies and Students' Perception of Team- Based Learning in Undergraduate Medical Education of a Medical School in Malaysia}

\author{
Shahid Hassan' , Mohd Salami Ibrahim², Nabiha Gul Hassan³ \\ ${ }^{1} I M U$ Centre of Education, International Medical University, Kuala \\ Lumpur, MALAYSIA \\ ${ }^{2}$ Faculty of Medicine, Universiti Sultan Zainal Abidin, Terengganu, \\ MALAYSIA \\ ${ }^{3}$ School of Health and Medical Sciences, Universiti Putra Malaysia, \\ Selangor, MALAYSIA
}

To cite this article: Hassan S, Ibrahim MS, Gul Hassan N. The structural framework, implementation strategies and students' perception of team-based learning in undergraduate medical education of a medical school in Malaysia. Education in Medicine Journal. 2018;10(1):55-68. https:// doi.org/10.21315/eimj2018.10.1.7

To link to this article: https://doi.org/10.21315/eimj2018.10.1.7

\title{
ABSTRACT
}

Delivery and implementation strategies are key to curriculum success. There is growing evidence that team-based learning (TBL) is an effective way of interactive teaching. TBL is a method that uses learning teams to enhance student engagement and quality of learning. Individual accountability for out-of-class reading is followed by individual and group assessment. In-class application exercises, which is the hallmark of team-based learning promotes both learning and team development. TBL uses educational principles of transforming traditional content into application of knowledge and problem solving skills in an interactive learning environment. To experience the structural framework and to determine the students' perception about TBL in clinical setting of MBBS program in a Malaysian medical school. A total of 120 students assigned to 22 small subgroups of 5-6 per group underwent a number of TBL sessions delivered in three phases. In Phase I, students were assigned reading material. In Phase II, students were assessed through One Best Answer (OBA) items for individual and group readiness assessment test as individual readiness assessment test (IRAT) and group readiness assurance test (GRAT) respectively followed by a mini-lecture. In Phase III, in-class application of learning activity was performed. Finally, peer assessment evaluated the contribution of peer in TBL. A TBL Classroom Evaluation Inventory (TBLCEI) developed to probe student's perception of TBL, comprised of 40 items composite scale with Cronbach's alpha at 0.881 . In addition, students were asked to provide their estimated grade in end of the posting assessment. Grades were categorised into excellent pass $>85 \%$, high pass $70 \%-$ $84 \%$; average to good pass $50 \%-69 \%$ and fail $<50 \%$. These grades were measured against students' TBLCEI survey score using analysis of variance (ANOVA). Results were considered significant at $p<0.05$. Results of one-way analysis of TBLCEI scores differed significantly across four estimated end of posting achievers groups, $\mathrm{F}(3,116)=52.279, p<0.001$. Bonferroni's procedure of multiple comparisons indicated that mean value of TBLCEI score of excellent pass significantly higher [70.90 (3.684)] than high pass [66.57 (3.625)], average to good pass [60.42 (3.583)] and fail [57.67 (5.626)] at $p<0.001$. It is concluded that medical students favourably liked TBL for interactive learning irrespective of their grades. A positive response for TBL from students is encouraging to consider 
switching over from traditional lecture to TBL in curriculum delivery. The students in TBL practice also delightfully embraced immediate feedback assessment technique (IF-AT) for partial credit based on number of attempts and selection of correct answer that was used in current study to score OBA in GRAT.

Keywords: Team-based learning, TBL framework, Students' perception, TBL classroom evaluation inventory, IF-AT System, Students' engagement

\section{INTRODUCTION}

Delivery and implementation strategies are key to curriculum success. Innovative teaching and learning methods such as problem-based learning (PBL) are developed to meet objectives of integrated and interdisciplinary curriculum particularly in the preclinical phase of a medical program. Over the last two decades, teambased learning (TBL) emerged as a new educational strategy to harness the benefits of small group learning within large classes (1).

\section{TBL: History and Structure}

Popularised by Larry Michaelsen in early 1990s at University of Oklahoma, TBL was conceptualised as an innovative educational strategy to promote active engagement and quality learning (2). TBL is a method that uses learning teams to enhance student engagement and quality of learning (3). The teamwork in TBL is ensured through a permanent, long-term team consisting of 5-7 students with evenly distributed diversity of skills. TBL begins with preclass student readings and completion of assignments usually one to three weeks before joining class $(4,5)$. In-class session starts with students taking an individual readiness assessment test (IRAT), which consists of approximately 10 multiplechoice questions (MCQs) preferably one best answer (OBA), testing the students' acquired knowledge from reading material often at factual recall to application level of Bloom's Taxonomy (6). IRAT is followed by a group readiness assurance test (GRAT). In GRAT same MCQs (OBAs) are administered for students to respond as a group who are provided with immediate feedback using an immediate feedback assessment technique (IF-AT).

IF-AT enables students to discuss each item in depth before scratching silver coding to reveal the correct answer. Every attempt taken to reach the right answer is provided with partial credit of a preselected rubric by the supervisor. IRAT and GRAT are subsequently followed by facilitator's feedback with an open book session allowing the students a right to appeal in case they disagree with their choice of the correct answer. Clearing misconceptions are collectively handled by a mini-lecture of 10-15 minutes in which all gray areas are identified and explained. Next steps include another in-class activity with application of knowledge using problem-based scenarios that require problem solving and criticalthinking skills to apply the newly acquired knowledge to solve problems. Ultimately, students will evaluate their peers in a realistic way to credit those who worked hard and contributed more in-group work versus those who did not work as hard.

Implemented in this way, TBL encourages individual accountability for out-of-class work such as reading and homework. The carefully designed and guided inclass application exercises, which is the hallmark of TBL, meanwhile, ensures group interaction, is mandatory to complete the assigned tasks (7). Incentives in the form 
of credit points will also be rewarded for working effectively as a team. These in turn, nurture the development of high levels of group cohesiveness and overcome the problems of free riders and members conflict (8).

\section{TBL: Theoretical Underpinning}

TBL uses educational principles of transforming traditional content (didactic lecture) into application of knowledge and skills in an interactive learning environment. TBL is specially designed to introduce comprehensive reading habits in an integrated curriculum, which aims to promote active learning and decrease formal lecture time. In basic sciences courses, it is possible to eliminate formal lectures and replace them by mini-lecture developed on students misconceptions identified during the TBL sessions. Mini-lectures are developed often with spot-on misconceptions picked up by supervisors and shown by students despite of comprehensive out of class reading and inside class activities based on concomitant learning and assessment sessions in TBL. A series of activities are provided to help students build baseline facts into a framework of conceptual interpretation and understanding $(9,10)$.

TBL encourages students to take the responsibilities of their own learning and actively participate in the process of learning under the supervision of a teacher as facilitator. TBL incorporates the main elements of constructivists learning, in which the focus is on acquiring new knowledge and understanding built upon inconsistencies and gaps between existing knowledge and new experiential learning contributed by peers, reading materials and teachers. TBL provides students with opportunities to reflect and make positive arguments as an individual and as a team, which promotes collaborative learning. TBL promotes interpersonal skills (11) with emphasis on learning how to learn, work, interact, and collaborate in a TBL environment (12). These active learning facilitate greater long-term knowledge retention compared to a traditional passive lecture-based curriculum (13). A focus on contextualised problem delivered with interactive discussion of students as a team promotes healthy learning environment and consolidate the process of learning.

\section{Literature Evidence}

There is growing evidence that TBL is an effective way of incorporating interactive small group peers teaching and enthusiasm for learning (14). In a medical gross anatomy course at the Wright State University School of Medicine, USA, it was demonstrated that students' steadily improve in day-to-day preparation to learning with corresponding reduction in examination's failure rate (15). A similar finding of improved attitude towards learning preparation was also reported at New Jersey Medical School, USA (16). In an earlier study at the same institution, it was also reported TBL implementation contributes to increased performance in examination score (5). A more comprehensive report on TBL showed that nine out of ten medical schools in USA which adopted TBL continued to do so after ten years with notable improvement in students' mastery of content, analytic reasoning, problem solving, teamwork skills, communication skills and knowledge outcome (17). In the context of basic science teaching, these achievements help students to construct relevant basic sciences concepts for in-class application of clinical problem solving $(9,10,15)$.

This subsequently promotes self-directed learning and enhances adaptability to problem solving situations (18). A Korean study of medical ethics and a USA study of medical anatomy showed TBL not only improves students who are academically weak, but also enhances achievement of excellent students $(19,20)$. A consistent finding also suggested that low-performing students appear to benefit more (21). Another study in comparison, showed not 
only students who took a biology course via TBL enjoyed overall improved academic performance; they also had less number of students dropped from the course compared with the group who underwent traditional lectures (22).

Active participation in an engaging environment appears to be the underpinning of these outcomes $(21,23)$. Students taught using TBL as a method of delivery of curriculum perform better in assessment with mastery of core knowledge and skills of course content $(15,16)$ compared to traditional methods (24). Faculty members perceive TBL for its impact on student behaviours, including being better prepared for class, more engaged during class, and taking more responsibility for their own learning (25). TBL also provides greater student to instructor engagement than traditional lecture during the learning process (13).

\section{Rationale of Study}

Despite growing evidence of its effectiveness, TBL implementation is still relatively new among medical institutions compared with other established pedagogy (1). To our knowledge, TBL does not appear to be a main method of teaching either during basic science or clinical science phase of a medical program in Malaysia's medical schools. Furthermore, studies which specifically explored student perception towards TBL class organisation, teamwork, teachers and students' role and performance appear to be limited. Hence, this study aims to evaluate students' perceptions of their TBL experiences on these domains via introduction of IF-AT scratch card system.

We aim to demonstrate practicality and positive outcomes of implementing TBL within Malaysian settings. Findings of this study will uniquely contribute to evidence of effective TBL implementation to facilitate decision making on shifting the emphasis of teaching and learning from traditional lectures towards TBL among Malaysian medical schools.

\section{METHODS}

One hundred and twenty of 4th year medical students from Universiti Sultan Zainal Abidin, UniSZA (58 from 2015 cohort and 62 from 2016 cohort during their ENT/Ophthalmology clinical posting) were recruited through convenience sampling in the study. Each cohort was divided into two equal halves and those posted to ENT further divided into two small groups of 15 to 17 students. Each group was then broken into five to six students per subgroup to undergo the TBL ENT teaching under the supervision of the lead author of this study. The TBL sessions covered three themes of clinical topic of sore throat, hoarseness and stridor which otherwise were traditionally delivered via a formal lectures. One hundred percent response rate with no missing data was recorded. Questionnaire was administered immediately after students have completed all three phases of TBL.

\section{TBL Classroom Environment Inventory (TBLCEI)}

A TBL Classroom Evaluation Inventory (TBLCEI) was developed (see Appendix) after a thorough review of the literature, which entailed compiling and adapting publicly available questionnaires pertaining to student preference for TBL $(26,27$, $28,29)$. The content experts opinion was also obtained to evaluate each item for its relevance to four factors inquired about students' perception of TBL, teamwork performance, teachers' role and students' performance. A pilot study was conducted in usual way to validate current TBL inventory addressing students' difficulty in understanding the items of inventory and experts' content opinion to avoid redundancy of items and all relevant aspects covered. Factor analysis, however, was beyond the scope of this study in which students' number were limited to meet the requirement of 5 subjects per item for principal component analysis, which in current study meant at least 200 students. A 
40 items TBLCEI was finally administered to probe student's opinion with 10 items each for TBL perception, teamwork performance, teachers' role and students' performance respectively (see Appendix). In view of reliability as internal consistency and not as dimensionality of 40 items composite score determined by Cronbach's alpha was as high as 0.881 for TBLCEI.

In addition, students were asked to provide their estimated grade in end of the posting assessment comprising of 15 multiple true false (MTF) questions, 5 OBA items, 2 problem based questions (PBQ) and 3 Objective Structured Clinical Examinations (OSCEs). Grades were categorised into excellent pass $>85 \%$, high pass $65 \%-74 \%$, average to good pass $50 \%-64 \%$, and fail $<50 \%$. Students estimated score leading to their own created grades categories were later verified with their actual achievement score at the end of posting (EOP) assessment. Students' own allocated grades were used to compare with their responses on TBLCEI using a 5-point Likert scale from $2,1,0,-1$ and -2 with a maximum score of +40 and a minimum score of -40 (see Appendix). The grades were compared against students' respondent score of TBLCEI, using analysis of variance (ANOVA). Results were considered significant at $p<0.05$.

\section{TBL Structure Used in Current Study}

\section{Phase-I TBL}

A total of 120 students assigned to 22 small subgroups were maintained throughout the posting. TBL was delivered in three phases (see Figure 1). In Phase I, students were assigned reading from carefully selected textbook and literature materials by the supervisor to help them prepare for IRATs. The same test was later administered to complete as GRATs. Reading materials were posted a week earlier than the actual TBL day, taking care not to overload them with weekend reading. Author restricted the reading to $20-30$ pages based on a theme (see Figure 1). Normally 30-50 pages with enough time to read are allowed in TBL.

\section{Phase-II TBL}

This phase of TBL started with IRAT, utilising 10 OBA items to be completed in 10 minutes (see Figure I). Later the same OBA items were administered for GRAT while facilitators marked the IRAT responses of every student. The score achieved by each student enabled the facilitator to know students' individual performance and give feedback if required. In GRATs students were given 20 minutes for 10 OBA items to discuss each item among the group members and respond with consensus by scratching an IF-AT Epstein Educational Enterprises, Cincinnati, $\mathrm{OH}$ scratch cards.

A 10 OBA items was developed to follow five options rectangle (see Figure 2) with four distractors and one correct answer (A, B, C, D, and E) according to the key provided by IF-AT scratch card system. After the team agreed to one choice answer, the rectangle thin silver opaque covering was scratched off. Immediate feedback provided with incorrect answer allowed students' to discuss the items with analytic reasoning before scratching the next rectangle in a collaborative environment. Additional choices until the correct answer were provided with partial credit using a preset rubric (see Figure 2). This was followed by brief feedback session from facilitator in which students were allowed to appeal however, providing authentic reference to support their viewpoint. This ultimately led to a mini-lecture of about 10-15 minutes that focused on students' misconceptions identified during IRAT and GRAT. 


\begin{tabular}{|c|c|c|}
\hline $\begin{array}{c}\text { Phase I } \\
\text { Pre-class Preparation } \\
\text { 1-3 Weeks Prior }\end{array}$ & $\begin{array}{c}\text { Phase II } \\
\text { In-Class Readiness Assurance } \\
1.5 \text { Hours }\end{array}$ & $\begin{array}{c}\text { Phase III } \\
\text { In-Class Application } \\
2-3 \text { Class Meetings }\end{array}$ \\
\hline \multirow{3}{*}{$\begin{array}{l}\text { Individual Study with } \\
\text { Preselected Reading } \\
\text { 20-30 Pages }\end{array}$} & $\begin{array}{l}\text { Individual Test (IRAT) } \\
10 \text { OBA Items (10 Minutes) }\end{array}$ & $\begin{array}{l}\text { Small Group Assignment for } \\
\text { Problem Solving }\end{array}$ \\
\hline & \multirow[t]{2}{*}{$\begin{array}{c}\text { Group Test (GRAT) } \\
\text { Same } 10 \text { OBA Items (20 Minutes) }\end{array}$} & $\begin{array}{l}\text { Intragroup Discussion for } \\
\text { Diagnosis }\end{array}$ \\
\hline & & Peer Evaluation \\
\hline \multirow{3}{*}{ Assessment } & Supervisor's Feedback & \multirow{3}{*}{ Assessment } \\
\hline & Mini-lecture (10-12 Minutes) & \\
\hline & Assessment & \\
\hline \multicolumn{3}{|c|}{$\begin{array}{c}\downarrow \quad \text { Individual Work } \\
\text { Assessment }=\text { Essay }(20 \%)+\text { IRAT }(20 \%)\end{array}$} \\
\hline \multicolumn{3}{|c|}{$\begin{array}{c}\text { Small Group Work Discussion } \\
\text { Assessment }=\text { GRAT }(20 \%)+\text { Group Assignment }(20 \%)\end{array}$} \\
\hline \multicolumn{3}{|c|}{ Total Class Discussion } \\
\hline
\end{tabular}

Figure 1: Three phases of TBL with assigned tasks and predecided percentage weighting of assessment practiced in current study.

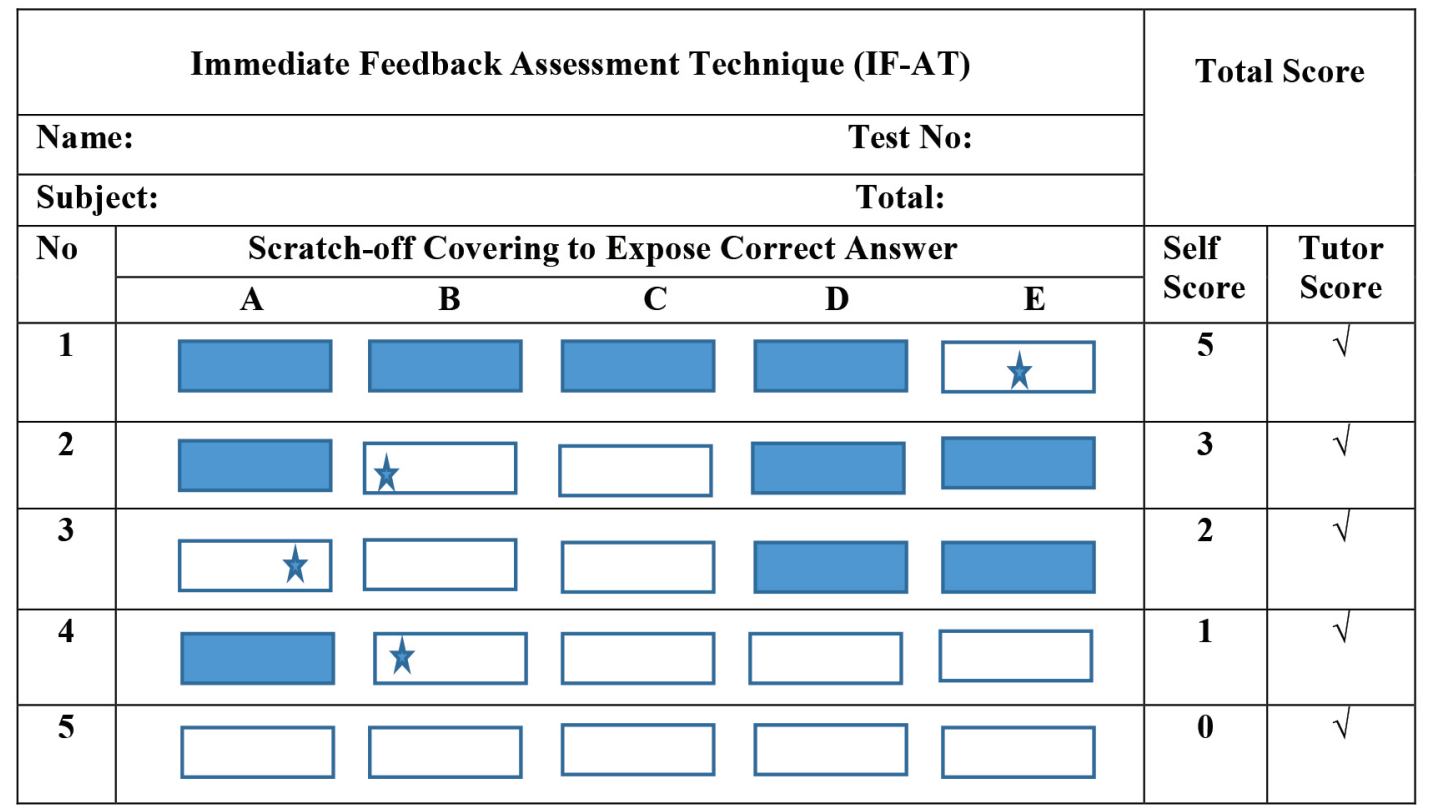

Figure 2: IF-AT scoring with five option list and scoring system of, 5 points for first choice, 3 points for second try, 2 points for third try, 1 point for fourth try, and 0 point for fifth try. 


\section{Phase-III TBL}

In Phase III, a subsequent in-class application of learning activity comprising of a significant problem that required students to make significant decision as a team. All teams worked on the same problem and at the same time and later reported simultaneously for intergroup discussion under supervision (see Figure 1). This was one of the most liked activities by the students. In this session students were asked to inform the class about their decision mostly set to diagnose. In a situation of disagreement among the teams, class was opened to debate on issues defending their viewpoints. Teacher in a facilitator role supervised the discussion with feedback if require. This session was also observed for students' performance as a team.

At the end of the session all students were advised to assess the contribution of their fellow members in the team for their participation in TBL. They were informed of rating criteria based on a realistic assessment rather than on friendship basis. Students were provided with guidelines (see Table 1) that help them to assign the score, which reflected a true judgement about the other members in their team for their contribution. Students accordingly acknowledged the contribution of those who worked harder than others in the team. Students were fully assured of confidentiality of peer assessment and provided with a a preset rubric (see Figure 1 and Table 2). Peer evaluation used a structured format that prevented them from unrealistic scoring. Ultimately students were graded by the facilitator taking into their individual (IRAT) as well as team performance (GRAT) of readiness assurance test, upheld appeals, in-class application activities and peer review score given by the students to each other (see Table 3). The students' performance was documented for reporting of coordinator.

Table 1: Instructions for informed peer assessment of group members except own assessment in a particular group

\begin{tabular}{ll}
\hline No. & \multicolumn{1}{c}{ Instructions for peer evaluation } \\
1 & List down the name of all members of the team ranked according to their score. \\
2 & Assign an overall average of 20 marks to all other members except you in team. \\
3 & $\begin{array}{l}\text { Differentiate performance of each member by giving one member at least } 21 \text { marks or higher } \\
\text { (maximum }=30 \text { ) and another member } 19 \text { marks or lower. }\end{array}$ \\
4 & $\begin{array}{l}\text { Ensure that overall marks assigned to all members in your team remains } 100 \text { points in case of } \\
5 \text { members, } 80 \text { points in case of } 4 \text { members and } 60 \text { points in case of } 3 \text { members in the team. }\end{array}$ \\
\hline
\end{tabular}

Table 2: Guidelines to mark students' performance with a preset rubric criteria and percentage weighting decided by the supervisor

Total points earned by a student in TBL is calculated from overall score obtained as:

Student Performance:

Individual Activities + Group Activities + Peer Evaluation

1. Individual Activities = IRAT + Individual Assignment (Essay)

2. Group Activities = GRAT + Group Assignment (Problem Solving)

3. Peer Evaluation: Calculated by Separate Team Maintenance Score Method 
Table 3: Group evaluation guideline checklist for supervisor in Phase III of TBL using a problem solving case and presenting for class interactive group discussion

\begin{tabular}{lccc}
\multicolumn{1}{c}{ Attribute } & \multicolumn{2}{c}{ Supervisor's assessment checklist for group performance } & Score \\
\hline Diagnosis & Incorrect (0) & - & Correct (5) \\
Group Interaction & Seldom (1) & Partial (3) & Thorough (5) \\
Knowledge Domain & Average (2) & Good (3) & Very good (5) \\
Confidence Level & Low (1) & Average (3) & High (5) \\
Group Attitude & Unsatisfying (0) & Partially Satisfying (3) & Satisfying (5) \\
\hline Total & Group overall performance based on supervisor's observation \\
\hline
\end{tabular}

\section{RESULTS}

All 120 respondents participated with their score of TBLCEI and estimated score of EOP assessment duly completed. Based on students' estimated score they were categorised into excellent pass $20(16.66 \%)$, high pass $37(30.83 \%)$, average to good pass $45(37.50 \%)$, and fail $18(15.00 \%)$. However, after the EOP assessment the ultimate grades of students were excellent pass $13.75 \%$, high pass $(35.50 \%)$, average to good pass $(41.29 \%)$, and fail $(9.45 \%)$.

One-way ANOVA was used to compare mean differences of TBLCEI score between different groups of estimated scores by students in EOP assessment. TBLCEI scores differed significantly across four estimated EOP achievers groups, $\mathrm{F}(3 ; 116)=52.279, p<0.001$ (see Table 4).

Post-hoc test Bonferroni's procedure was applied because Levene test assumptions for homogeneity was met with variances for each group of estimated score equal at $p$ value not significant (0.317). Multiple comparisons indicated that mean value of TBLCEI score of excellent pass significantly higher $[70.90(3.684)]$ than high pass [66.57 (3.625)], average to good pass $[60.42(3.583)]$, and fail $[57.67(5.626)]$ at $p<0.001$ (see Figure 3).

Table 4: Mean TBLCEI score among students with different estimated achievement scores among high pass, good pass, pass and fail in EOP assessment

\begin{tabular}{|c|c|c|c|c|}
\hline Variable of estimated score & Number & $\begin{array}{l}\text { TBLCEI score mean } \\
\text { (SD) }\end{array}$ & F-statistics ${ }^{a}(\mathrm{df})$, & $p$-value \\
\hline Excellent Pass & 20 & $70.90(3.684)$ & \multirow{4}{*}{$52.279(3 ; 116)$} & \multirow{4}{*}{$<0.001^{b}$} \\
\hline High Pass & 37 & $66.57(3.625)$ & & \\
\hline Average to Good Pass & 45 & $60.42(3.583)$ & & \\
\hline Fail & 18 & $57.67(5.626)$ & & \\
\hline
\end{tabular}

Notes:

a: One-Way ANOVA test

b: TBLCEl estimated scores of excellent pass, high pass, average to good pass and fail were significantly different at $p<0.001$ by post-hoc test Bonferroni's procedures. 


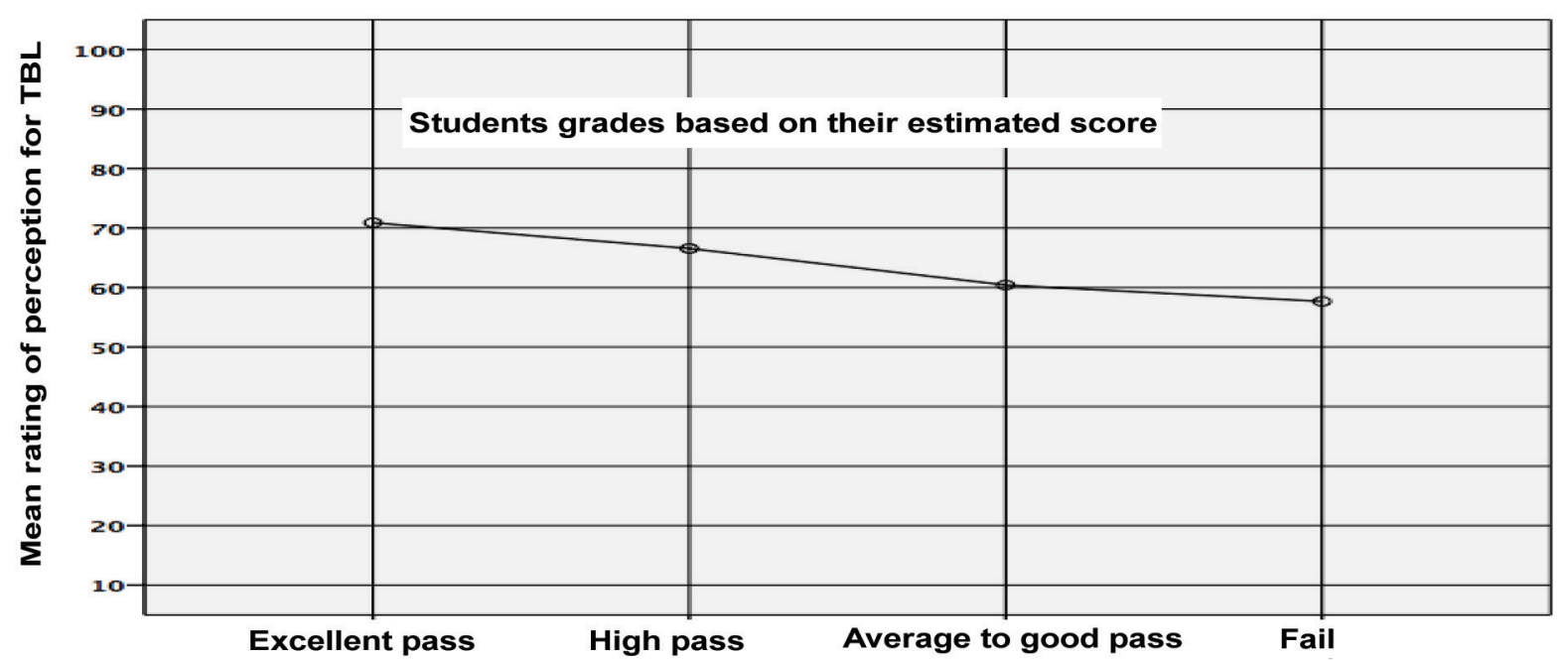

Figure 3: Mean rating score of perception for TBL by students estimated score for grading in EOP assessment.

\section{DISCUSSION}

In curriculum, delivery methods of teaching and learning has long been debated and questioned in literature. Formal or traditional lectures are the most commonly employed method used in problemoriented teaching and perhaps need to be restricted in curriculum. For long, lectures have been delivered in isolation and with monotonous uniform formats, hindering analytic reasoning skills and deeper learning approaches (30). The emphasis in curriculum delivery currently is on interactive lectures and ways to reduce didactic delivery. Basic sciences teachers in the preclinical phase of undergraduate medical education commonly ask, how to accomplish given curriculums without formal lectures in place. Yet, student-centred learning demands a curriculum that has as many self-study slots as face-to-face learning slots in students' daily teaching and learning activities. One option is to find a new delivery method in curriculum implementation that can replace didactic lectures by interactive lectures achieving both students' engagement as well as coverage of topics (lessons) that remain the same in an integrated curriculum.

TBL is capable to fulfill these needs. TBL can be delivered within a large-group setting while ensures feedback on tasks performed is frequent on both, individual and team efforts at various steps in the process (see Tables 2 and 3). Realistic peer feedback is another important feature of TBL that acknowledges peer appreciation for hardworking colleagues. Students in TBL learn to know the significance of authentic versus casual peer rating (23) and this has also been observed in current study (see Table 1). The current study indicates that TBL reduces faculty burnout by promoting increased student responsibility, engagement in the learning process, and increased opportunities for positive teacher-student interactions. TBL as implemented in this study devoted most of in-class time to small group activities, necessitating a shift in the role of the instructor from dispenser of information to manager of the learning process. Surprisingly it was also found that classroom attendance improved and so did the motivation of students' in their efforts to do pre-class preparation. It is further observed that TBL has also helped students to clear their misconceptions and enhance interpersonal and team skills, in a class of 20 to 30 students. It motivated students to learn how to learn, work as a team, and interact collaboratively to solve a problem.

TBL was found to help students who are not interested in subject matters, who do 
not complete their homework, and who have difficulty in understanding the subject (31). TBL transforms traditional content into problem solving case scenario while employing an interactive learning approach. TBL is especially useful where tasks performed as a team are to be accomplished as a project or assignment (32). TBL is also important for greater long-term knowledge retention. Teaching the students with TBL increases students' engagement in an outcome-based education with opportunities of frequent and immediate feedback using IF-AT scratch card system. Apart from receiving feedback students also learned to experience realistic peer evaluation based on informed peer assessment in current study (see Table 1).

Results of one-way ANOVA between excellent pass/high pass/average to good pass and fail students indicated that excellent pass rated perceptions of TBL, performance of teamwork and supervisor and students' role higher than high pass, average to good pass, and fail categories of students' performance (see Table 4). However, each had overall positive ratings and it is observed that students favourably liked TBL for interactive learning irrespective of their grades (see Figure 3). A positive response for TBL from students is encouraging to consider switching over from traditional to TBL in delivery of curriculum in future. TBL can easily transform traditional content into problem solving case scenarios, requiring an interactive approach. It has been understood that students' liking for TBL because of their engagement marked with opportunities of frequent and immediate feedback using IF-AT scratch cards. IF-AT system has also helped supervisors to conveniently practice partial credit system.

\section{CONCLUSION}

Introducing TBL in clinical teaching was a good experience with regard to TBL format practiced in three phases. TBL in current study was developed for guidelines of its implementation, supervisor's scoring rubric, peer evaluation procedure, IRAT, GRAT, mini-lecture, problem-solving scenarios and partial credit using IF-AT system, for the first time ever in a medical school in Malaysia. Students' preparedness for classes after reading through the preclass assignments of textbook and literature material was another achievement observed in this study. Students also learned how to give a meaningful and realistic peer evaluation. It is concluded that medical students favourably liked TBL for interactive learning irrespective of their grades. A positive response for TBL from students is encouraging to consider switching over from traditional to TBL in delivery of curriculum in future. 


\section{APPENDIX}

A 40 items TBL Classroom Environment Inventory (TBLCEI) with 5-point Likert scale rubric of, strongly agree $=$ 2 , agree $=1$, not sure $=0$, strongly disagree $=-2$, disagree $=-1$

"This TBLCEI shall not be reproduced without prior permission from the author"

\begin{tabular}{|c|c|c|c|c|c|c|}
\hline No & & $\begin{array}{l}\text { Strongly } \\
\text { agree }\end{array}$ & Agree & $\begin{array}{l}\text { Not } \\
\text { sure }\end{array}$ & $\begin{array}{l}\text { Strongly } \\
\text { disagree }\end{array}$ & Disagree \\
\hline & Factor I: Perception of TBL & & & & & \\
\hline 1 & $\begin{array}{l}\text { Reading through the pre-classroom material } \\
\text { provided by supervisor was helpful }\end{array}$ & & & & & \\
\hline 2 & $\begin{array}{l}\text { TBL helped me increase my understanding of } \\
\text { course material in curriculum }\end{array}$ & & & & & \\
\hline 4 & $\begin{array}{l}\text { Individual readiness assurance tests (IRATs) } \\
\text { were useful learning activities }\end{array}$ & & & & & \\
\hline 5 & $\begin{array}{l}\text { Group readiness assurance tests (GRATs) } \\
\text { allowed me to correct my misconceptions }\end{array}$ & & & & & \\
\hline 6 & $\begin{array}{l}\text { I learned useful additional information in TBL } \\
\text { compared to traditional lectures }\end{array}$ & & & & & \\
\hline 7 & $\begin{array}{l}\text { The TBL format was helpful in developing my } \\
\text { information synthesizing skills }\end{array}$ & & & & & \\
\hline 8 & $\begin{array}{l}\text { Immediate feedback assessment technique } \\
\text { (IF-AT) was interesting experience in TBL }\end{array}$ & & & & & \\
\hline 9 & $\begin{array}{l}\text { Partial credit system in GRAT helped me in } \\
\text { building my critical thinking }\end{array}$ & & & & & \\
\hline \multirow[t]{2}{*}{10} & $\begin{array}{l}\text { TBL helped me in the preparation of my end of } \\
\text { the posting assessment }\end{array}$ & & & & & \\
\hline & Factor II: Performance of Teamwork & & & & & \\
\hline 11 & $\begin{array}{l}\text { Interactive group activity with clinical oriented } \\
\text { problem improved my problem solving skills }\end{array}$ & & & & & \\
\hline 12 & $\begin{array}{l}\text { Classroom assignments with interactive group } \\
\text { encounters helped us worked as a team in TBL }\end{array}$ & & & & & \\
\hline 13 & $\begin{array}{l}\text { All teammates demonstrated mutual respect } \\
\text { for each other viewpoints during TBL }\end{array}$ & & & & & \\
\hline 14 & $\begin{array}{l}\text { I have a positive attitude about working as a } \\
\text { team in TBL sessions }\end{array}$ & & & & & \\
\hline 15 & $\begin{array}{l}\text { Students were more engaged in classroom } \\
\text { activities as a group during TBL sessions }\end{array}$ & & & & & \\
\hline 16 & $\begin{array}{l}\text { I am satisfied of my meaningful contribution } \\
\text { to the } T B L \text { discussions }\end{array}$ & & & & & \\
\hline 17 & $\begin{array}{l}\text { The ability to collaborate with my peers is } \\
\text { necessary if I am to be successful as a student }\end{array}$ & & & & & \\
\hline 18 & $\begin{array}{l}\text { Solving problems in a group is an effective } \\
\text { way to learn problem-solving skills }\end{array}$ & & & & & \\
\hline 19 & $\begin{array}{l}\text { Working in groups, TBL provided me more } \\
\text { opportunity to think critically }\end{array}$ & & & & & \\
\hline 20 & $\begin{array}{l}\text { I prefer TBL format over traditional lecture for } \\
\text { sharing of knowledge in collaborative learning }\end{array}$ & & & & & \\
\hline
\end{tabular}




\begin{tabular}{|c|c|c|c|c|c|c|}
\hline No & & $\begin{array}{l}\text { Strongly } \\
\text { agree }\end{array}$ & Agree & $\begin{array}{l}\text { Not } \\
\text { sure }\end{array}$ & $\begin{array}{l}\text { Strongly } \\
\text { disagree }\end{array}$ & Disagree \\
\hline & Factor III: Perception of Teacher & & & & & \\
\hline 21 & $\begin{array}{l}\text { Teacher is responsible for class organization } \\
\text { however, in facilitator role in TBL sessions }\end{array}$ & & & & & \\
\hline 22 & $\begin{array}{l}\text { Teacher considers students' feelings in TBL and } \\
\text { he is more considerate towards students }\end{array}$ & & & & & \\
\hline 23 & $\begin{array}{l}\text { Teacher often observes and talks individually } \\
\text { to students in TBL as required }\end{array}$ & & & & & \\
\hline 24 & $\begin{array}{l}\text { Teacher listens more than he talks to students } \\
\text { in TBL sessions }\end{array}$ & & & & & \\
\hline 25 & $\begin{array}{l}\text { Teacher moves around the classroom } \\
\text { and observes their individual and group } \\
\text { performance }\end{array}$ & & & & & \\
\hline 26 & $\begin{array}{l}\text { In TBL traditional lectures converted to } \\
\text { a mini-lectures is focused on students' } \\
\text { misconceptions }\end{array}$ & & & & & \\
\hline 27 & $\begin{array}{l}\text { Teacher's time management in organizing TBL } \\
\text { sessions is according to plan }\end{array}$ & & & & & \\
\hline 28 & $\begin{array}{l}\text { Teachers do not dominate classroom } \\
\text { discussion among the groups }\end{array}$ & & & & & \\
\hline 29 & $\begin{array}{l}\text { Classroom activities are carefully planned with } \\
\text { all relevant materials provided }\end{array}$ & & & & & \\
\hline \multirow[t]{2}{*}{30} & $\begin{array}{l}\text { Teaching approaches are characterized by } \\
\text { innovation and variety in TBL }\end{array}$ & & & & & \\
\hline & Factor IV: Performance of Students & & & & & \\
\hline 31 & $\begin{array}{l}\text { Students look forward to attending TBL classes } \\
\text { with interest }\end{array}$ & & & & & \\
\hline 32 & $\begin{array}{l}\text { Students know exactly what they are going to } \\
\text { do in TBL sessions }\end{array}$ & & & & & \\
\hline 33 & $\begin{array}{l}\text { All the students in the class are expected to do } \\
\text { the same work at the same time }\end{array}$ & & & & & \\
\hline 34 & $\begin{array}{l}\text { Each student knows the other member in the } \\
\text { group for their contribution and teamwork }\end{array}$ & & & & & \\
\hline 35 & $\begin{array}{l}\text { Students put efforts into what they do in the } \\
\text { TBL sessions in classroom }\end{array}$ & & & & & \\
\hline 36 & $\begin{array}{l}\text { Students feel satisfied what is done in the } \\
\text { classroom in TBL }\end{array}$ & & & & & \\
\hline 37 & $\begin{array}{l}\text { Students have the opportunity to present their } \\
\text { work in class during the TBL sessions }\end{array}$ & & & & & \\
\hline 38 & $\begin{array}{l}\text { Class assignments are clear to everyone as } \\
\text { what to do in the classroom }\end{array}$ & & & & & \\
\hline 39 & $\begin{array}{l}\text { Students are allowed to set their own pace of } \\
\text { learning as how they will work }\end{array}$ & & & & & \\
\hline 40 & $\begin{array}{l}\text { Peer evaluation is more realistic based on } \\
\text { students' actual performance during TBL }\end{array}$ & & & & & \\
\hline
\end{tabular}




\section{REFERENCES}

1. Parmelee D, Michaelsen L, Cook S, Hudes P. Team-based learning: a practical guide. AMEE Guide No. 65. Med Teach. 2012;34(5):e275-87. https://doi.org/10.3109 /0142159X.2012.651179

2. Michaelsen L, Richards B. Drawing conclusions from the team-learning literature in health-sciences education: a commentary. Teach Learn Med. 2005;17(1):85-8. https:// doi.org/10.1207/s15328015tlm1701_15

3. Michaelsen LK, Watson WE, Cragin JP, Fink LD. Team-based learning: a potential solution to the problems of large classes. Exchange: The Organizational Behavior Teaching Journal. 1982;7(4):18-33.

4. Koles PG, Stolfi A, Borges NJ, Nelson S, Parmelee DX. The impact of team-based learning on medical students' academic performance. Acad Med. 2010;85(11):173945. https://doi.org/10.1097/

ACM.0b013e3181f52bed

5. Ofstad W, Brunner LJ. Team-based learning in pharmacy education. Am J Pharm Educ. 2013;77(4):70. https://doi.org/10.5688/ ajpe 77470

6. Allen RE, Copeland J, Franks AS, Karimi R, McCollum M, Riese DJ, et al. Team-based learning in US colleges and schools of pharmacy. Am J Pharm Educ. 2013;77(6):115. https://doi.org/10.5688/ ajpe 776115

7. Michaelsen LK. Getting started with teambased learning. In: Michaelsen LK, Knight AB, Fink LD, editors. Team-based learning: a transformative use of small groups. New York: Greenwood Publishing Group; 2002.

8. Michaelsen LK, Knight AB, Fink LD. Teambased learning: a transformative use of small groups in college teaching. Westport, CT: Praeger Publishing; 2004.
9. Vasan NS, DeFouw DO, Holland BK. Modified use of team-based learning for effective delivery of medical gross anatomy and embryology. Anat Sci Educ. 2008;1(1):3-9. https://doi.org/10.1002/ase.5

10. Vasan NS, DeFouw D. Team learning in a medical gross anatomy course. Med Educ. 2005;39(5):524. https://doi.org/10.1111/ j.1365-2929.2005.02146.x

11. Hills H. Team-based learning. England: Gower; 2001. p. 157.

12. Association of American Medical Colleges. Team based learning. USA: AAMC; 2018 [cited 2018 February 15]. Available from: https://www.aamc.org/download/154730/ data/rime_poster_109.pdf.

13. Kelly PA, Haidet P, Schneider V, Searle N, Seidel CL, Richards BF. A comparison of in-class learner engagement across lecture, problem-based learning, and team learning using the STROBE classroom observation tool. Teach Learn Med. 2005;17(2):112-8. https://doi.org/10.1207/ s15328015tlm1702_4

14. Parmelee DX. Team-based learning in health professions education: why is it a good fit? In: Michaelsen LK, Billings DM, editors. Team-based learning for health professions education: a guide to using small groups for improving learning. 1st ed. Sterling, VA: Stylus, 2008. p. 3-8.

15. Nieder GL, Parmelee DX, Stolfi A, Hudes PD. Team-based learning in a medical gross anatomy and embryology course. Clin Anat. 2005;18(1):56-63. https://doi.org/10.1002/ ca. 20040

16. Vasan NS, DeFouw DO, Compton S. A survey of student perceptions of team-based learning in anatomy curriculum: favorable views unrelated to grades. Anat Sci Educ. 2009;2(4):150-5. https://doi.org/10.1002/ ase. 91 
17. Thompson BM, Schneider VF, Haidet P, Levine RE, McMahon KK, Perkowski LC, et al. Team-based learning at ten medical schools: two years later. Med Educ. 2007;41(3):250-7. https://doi.org/10.1111/ j.1365-2929.2006.02684.x

18. Garland D. Assessment issues in-group work. In: Foot HC, Howe CJ, Anderson A, Tolmie A, Warden D, editors. Group and interactive learning. Southampton: Computational Mechanics Publications; 1994. p. 417-22.

19. Chung EK, Rhee JA, Baik YH, A OS. The effect of team-based learning in medical ethics education. Med Teach. 2009;31(11):1013-7. https://doi. org/10.3109/01421590802590553

20. Vasan NS, DeFouw DO, Compton S. A survey of student perceptions of team-based learning in anatomy curriculum: favorable views unrelated to grades. Anat Sci Educ. 2009;2(4):150-5. https://doi.org/10.1002/ ase. 91

21. Davidson LK. A 3-year experience implementing blended TBL: active instructional methods can shift student attitudes to learning. Med Teach. 2011;33(9):750-3. https://doi.org/10.3109/0 142159X.2011.558948

22. Carmichael J. Team-based learning enhances performance in introductory biology. Journal of College Science Teaching. 2009;38(4):5461.

23. Abdelkhalek N, Hussein A, Gibbs T, Hamdy H. Using team-based learning to prepare medical students for future problem-based learning. Med Teach. 2010;32(2):123-9. https://doi.org/10.3109/01421590903548539

24. Fatmi M, Hartling L, Hillier T, Campbell S, Oswald AE. The effectiveness of team-based learning on learning outcomes in health professions education: BEME Guide No. 30. Med Teach. 2013;35(12):e1608-24. https:// doi.org/10.3109/0142159X.2013.849802
25. Nelson $\mathrm{MH}$, Dean Allison SD, McCollum M, Luckey SW, Clark DR, Paulsen SM, et al. The Regis model for pharmacy education: a highly integrated curriculum delivered by Team-Based Learning ${ }^{\mathrm{TM}}$ (TBL). Currents in Pharmacy Teaching and Learning. 2013;5(6):555-63. https://doi.org/10.1016/j. cptl.2013.07.002

26. Dunaway GA. Adaption of team learning to an introductory graduate pharmacology course. Teach Learn Med. 2005;17(1):56-62. https://doi.org/10.1207/ s15328015tlm1701_10

27. Wiener H, Plass H, Marz R. Team-based learning in intensive course format for firstyear medical students. Croatian Medical Journal. 2009;50(1):69-76. https://doi. org/10.3325/cmj.2009.50.69

28. Parmelee DX, DeStephen D, Borges NJ. Medical students' attitudes about teambased learning in a pre-clinical curriculum. Med Educ Online. 2009;14:1. https://doi. org/10.3325/cmj.2009.50.69

29. Gallegos P, Peeters M. A measure of teamwork perceptions for team-based learning. Currents in Pharmacy Teaching and Learning. 2011;3(1):30-5. https://doi. org/10.1016/j.cptl.2010.10.004

30. Schmidt HG, de Volder ML, De Grave WS, Moust JC, Patel VL. Explanatory models in the processing of science text: the role of prior knowledge activation through smallgroup discussion. Journal of Educational Psychology. 1989;81(4):610-9. https://doi. org/10.1037/0022-0663.81.4.610

31. Ward M, Gruppen L, Regehr G. Measuring self-assessment: current state of the art. Adv Health Sci Educ Theory Prac. 2002;7(1):63-80. https://doi. org/10.1023/A:1014585522084

32. Ashraf MA. Critical look at the use of group projects as a pedagogical tool. Journal of Education for Business. 2004;79(4):213-6. https://doi.org/10.3200/JOEB.79.4.213-216 